\title{
ORGANIZATIONAL FACTORS, ORGANIZATIONAL CULTURE, JOB SATISFACTION AND ENTREPRENEURIAL ORIENTATION IN PUBLIC ADMINISTRATION
}

\author{
Konstantinos M. Karyotakis, Vassilis S. Moustakis \\ Technical University of Crete \\ Management Systems Laboratory (ManLab) \\ School of Production Engineering and Management \\ Chania 73100, Greece
}

\begin{abstract}
:
The present paper outlines the critical role and influence of organizational culture and job satisfaction on the relationship between organizational factors and entrepreneurial orientation (EO) in the public sector through generating the theoretical framework. Upon examining these terms, a model that reflects their mutual relationships has been suggested. The amalgam of internal work environment, work discretion and rewards/ recognition in combination with the appropriate degree of organizational boundaries, such as formalization, centralization, technology routines and connectedness, are crucial for fostering organizational culture and job satisfaction that lead to EO through innovativeness, proactiveness and risk taking.
\end{abstract}

\section{Key words:}

organizational culture, learning organization, job satisfaction, entrepreneurial orientation (EO), public sector.

\section{INTRODUCTION}

Today's organizations are bigger and more complex than ever. In order to successfully respond to the newly emerging conditions and constantly increasing needs of citizens, public administration should be more oriented towards the use of efficient methods, practices and procedures (Karyotakis \& Moustakis, 2014).

It is generally thought that there are notable malfunctions in the public sector, not only in terms of efficiency and efficacy, but also in terms of legitimacy. Nonetheless, a wide range of innovations take place in this sector, from technologi- $\mathrm{cal}$ and reengineering processes to organizational and conceptual innovations (Bekkers et al., 2009). Daily examples of administrative innovations constitute the usage of indicators that measure the results and various efficiency evaluation mechanisms of public services.

Attitudes, behavior and practices containing the elements of innovation and entrepreneurship are encountered as strategies that advocate for change (Karyotakis et al., 2015). Indeed, considerable endeavors have been initiated in the public sector, especially in the last 15 years, in order to evolve into a more flexible, efficient and effective form (Zampetakis \& Moustakis, 2010). 
Changes accomplished at all levels worldwide meet the expectations of citizens and competition authorities through benchmarking and adoption of best practices of private and public services. The role of the state is redefined on a day-to-day basis with the aim to coordinate and meliorate its management, organization, operations and functions via reform policies, reinvention, restructuring, reengineering and redefining appropriate adjustment of methods and practices to the local peculiarities.

Innovation and its diffusion, as well as the entrepreneurial orientation (EO), are of vital importance in the change process. Last but not least, administrative accountability and executive functioning of public organizations should be amplified by appropriate strategic programs. The simplification of procedures in the public sector is more imperative than ever in order to have faster, more friendly, efficient, effective, productive, qualitative and flexible services.

Moreover, costs and administrative burdens should be reduced, using computerization, digital services and e-government more widely, tracking simultaneously administrative actions. Transparency, trust and meritocracy must be strengthened, and the war against corruption must be fought. Economic growth must be supported, as well as entrepreneurship and innovation (Karyotakis \& Moustakis, 2014).

\section{NECESSARY COMPONENTS FOR SURVIVAL AND EVOLUTION}

Creativity, innovation, strategic thinking and entrepreneurship in terms of products and services are essential for the survival, growth, evolution and profitability of organizations. However, there is no doubt that entrepreneurial attitudes and behavior must be adjusted to the dynamic and changing conditions.

Innovative and entrepreneurial behavior is necessary in all human actions, regardless of their nature (Shockley et al., 2002). However, the terms "entrepreneur" and "entrepreneurship" are inextricably linked with uncertainty, ambiguity and the unknown (Hamilton \& Harper, 1994). Tolerated behavior inclines to be more innovative, risky and proactive. Successful entrepreneurs take manageable risks in order to schedule their potential rewards.

New behavioral archetypes and EO can increase the prosperity of the community through appropriate resource management, providing high-quality public services (Karyotakis et al., 2015). Due mainly to the size and heterogeneity of these organizations, innovative and entrepreneurial solutions are imposed. Zampetakis and Moustakis (2007) claim that the social welfare attained has more than personal or economic objectives. Likewise, Benz (2009) claims that the benefits of entrepreneurial behavior are primarily non-profit.

Entrepreneurship drives to social, economic, and political innovation. This innovation is "creatively destructive" (Schumpeter, 1934). Nevertheless, before each innovation process, some factors should be taken into account:

- the import, the adoption or the mining cost of innovation,

- the potential benefits for the community,

- the potential negative reverberations and

- the required time availability.

Innovations may be useful for some citizens, for the whole community and/or for the employees themselves.

\section{Innovation}

Innovation can influence the long-term viability of a business, as well as social and economic change (Wu, 2011). However, factors such as goal clarity, time availability, resources, equipment, services and autonomous work environment are required for adoption of innovative ideas (Yuan \& Woodman, 2010).

An innovative organizational environment encourages creativity, risk-taking, autonomy, freedom, teamwork, trust, respect, communication, 
flexible and relatively instant solutions (Dobni, 2008). Furthermore, innovation prospers in environments where appropriate conditions thrive, and focuses on factors such as mission, vision, customer, management processes, support mechanisms, leadership and employee constituency (Martins \& Terblanche, 2003).

Innovation in the public sector contributes to open government, and can be stimulated through continuous training and learning orientation in combination with continuous evaluation, financial and administrative incentives, adding value to the outcome. Nevertheless, there is no integrated framework for comprehending and measuring innovation in this sector (Koch \& Hauknes, 2005).

In the public sector, value can be created by social outcome, services or trust. Increased efficiency, improved quality, user satisfaction, greater usage of services, greater equity (fairness) in service provision or greater choice or variety, constitute facets of value creation in services.

\section{Entrepreneurship}

Currie et al. (2008) define entrepreneurship as the process of recognizing and pursuing opportunities by individuals and/or organizations. Entrepreneurship can be viewed as "the process of creating value by bringing together a unique package of resources to exploit an opportunity" (Drucker, 1985; Kao, 1989).

Entrepreneurship takes place in any organization of any size or form (private sector, public sector, non-profit sector). Indeed, large traditional organizations are encouraged to adopt entrepreneurial behavior in order to ameliorate their performance. Entrepreneurial behavior adds value to an organization as it affects the way in which bureaucracy is confronted and strategic vision is envisaged, forming a more energetic environment characterized by a change of orientation ( $\mathrm{Wu}, 2011)$.

Leadbeater and Goss (1998) espouse the opinion that there is much more entrepreneurship in the public sector than it is actually believed.
Indeed, appropriate organizational changes and administrative practices and processes can energize entrepreneurship forms (Zampetakis, 2007). Schumpeter (1934) conjectures that EO is the most effective strategy that should be followed in order to survive a deep economic downturn.

The organizational reform of the public sector from a traditional and bureaucratic form to a more entrepreneurial form is inevitable for economic development and prosperity. In more heterogeneous and turbulent environments, more systemic public entrepreneurship is highly needed taking into account a wide range of people, institutionalizing and affecting a notable portion of organizational functions and operations (Scott, 2001).

\section{CULTURE AND CHANGE PROCESS}

It is essential to develop and nurture an entrepreneurial organizational culture that will encourage flexibility, undertaking of initiatives, autonomy, freedom and finding direct and innovative solutions that will focus on human resources, creation and knowledge management, as well as on development of a partner-like relationship among public servants, state, society, private sector and non-profit organizations. Such culture should go beyond legalism, formalism, inertia and overspending, serving the society and the economy without oppressing the citizens.

In this way, red-tape is minimized and both processes and procedures are optimized. The ultimate goal of previous actions is to have effective and efficient citizen's services that will satisfy the needs of both employees and citizens. It will be characterized by quality, transparency, accountability, extroversion, value, rules and result orientation.

Another important aspect is the fact that maturity, justice and objectivity are the points to social and political level that focus on the creation and evolvement of the successful change process. This culture should be espoused by every employee, improving his/her readiness to change and limiting the phenomena of resistance to change. 
Based on the above-stated, it is more than obvious that human resources constitute public administration. Therefore, employees who have to actively participate in the change process are the lever for the public sector modernization, constituting part of this and embodying it in their daily practices, attitudes and behavior.

When someone refers to modernization, he/she usually relates to the change process. It is recommended to advocate organizational culture that will support readiness to change and will not be close-minded and resistant to change (Karyotakis \& Moustakis, 2014).

Moustakis (2012) supports the claim that the change process in an organization is the outcome of the following factors:

$$
K x C x W
$$

where:

$\mathrm{K}=$ Know. Organization members should clearly know what they should do.

$\mathrm{C}=$ Can. Organization members should have the ability or the opportunity to perform the task.

$\mathrm{W}=$ Want. Organization members should have the willingness to perform the task.

If any factor of (1) is zero, or tends to zero, the total outcome will be zero or will tend to zero, too. Bowen (1986) emphasizes the willingness of human resources to accept or reject any change. Their willingness greatly determines the success of an organization. Bowen (1986) assigns more relevance to the factor $\mathrm{W}$ of (1).

However, not all the people are considered equally important assets in an organization, but only the right people (Collins, 2001). The term right people refers to their technical knowledge, academic qualifications, skills, etc. Additionally, diversity among employees may encourage the exchange of ideas, thus facilitating the learning process (Kearney \& Gebert, 2009).

The mapping and evaluation of knowledge and skills (qualifications) of civil servants, which will be well described through properly position outlines (mobility), will redistribute them in the appropriate workstation and can lead to the rational use of human resources.

\section{Learning Organizations}

Last but not least, public organizations should evolve into learning organizations through continuous learning, attitudes, practices and behavior, appropriate staffing, administrative ethos and interactive communication within and outside the organization in order to survive and adapt to dynamic and constantly changing environment. Benchmarking policies lead to identification of best management practices and organizational learning via knowledge diffusion and transfer policy.

\section{PROPOSED MODEL}

The present article attempts to formalize the relationships among the key constructs that connect organizational and structural factors that drive to EO through organizational culture and job satisfaction (mediators). Based on the literature research, this contribution concludes with four specific organizational dimensions (internal work environment, work discretion, rewards/recognition and organizational boundaries), which in combination with four structural dimensions (formalization, centralization, technology routines and connectedness) constitute the crucial elements of an internal work environment that lead to EO, as shown in Figure 1.

Each determinant is briefly examined below from the employee perspective.

\section{ORgANIZATIONAL FACTORS}

\section{Internal work environment}

Management and coworker support are considered an organization's internal work environment. The term management support implies the extent to which an employee perceives and the 


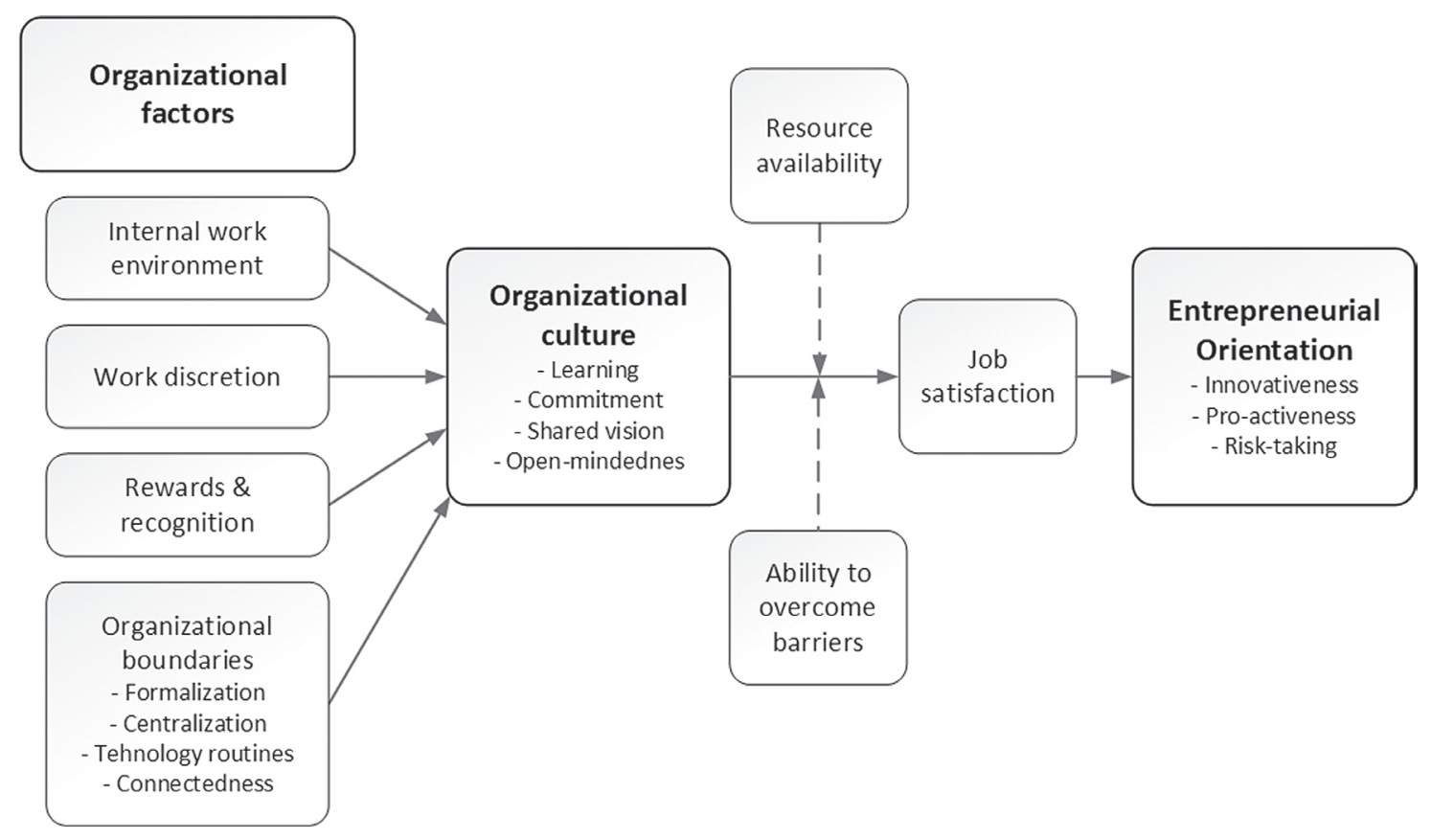

Figure 1. Conceptual model shows the effects of organizational factors on job satisfaction through organizational culture (mediator) and the effects of organizational culture on Entrepreneurial Orientation through job satisfaction (mediator). Moderating effects suggest that resource availability and ability to overcome barriers strengthen the job satisfaction to Entrepreneurial Orientation relationship.

ways in which the upper managers' countenance facilitates and boosts entrepreneurial behavior (Kuratko et al., 2014). When top management supports entrepreneurial behavior (such as innovative, proactive and risk-taking behavior), middle managers are more likely to behave in this way and vice versa (Meynhardt \& Diefenbach, 2012).

The perception of management support encourages creative ideas and explores new opportunities, promoting their implementation through the sense of participation and contribution that is spread among employees (Calantone et al., 2002). Management support is the cornerstone for creative and discretionary behavior.

This support undoubtedly constitutes the vehicle of each organization through which an employee can innovate (Ma Prieto \& Perez-Santana, 2014). Furthermore, colleagues' trust is positively related to proactive behavior (Parker et al., 2006). Cooperation encourages knowledge sharing, adoption and creation, forging a friendly to innovation work environment (Hsu et al., 2007).
Additionally, Parker et al. (2006) claim that management and coworker support are the elements of supportive internal work environment which significantly influences innovative work behavior, inciting proactively and expanding employee's self-perception. Assuredly, support is of vital importance in such innovative and unpredictable work environments.

\section{Work discretion}

The perception that an organization encourages testing and experimentation, recognizing the possibility of failure through adoption of fewer strict rules and procedures, allows for decisionmaking and provides relative flexibility to lowerlevel managers and employees (Kuratko et al., 2014). Work discretion provides middle management with the opportunity to innovate and behave more entrepreneurially (Meynhardt \& Diefenbach, 2012). 


\section{Rewards/recognition/reinforcement}

The perception that rewards systems based on EO, performance and success are encountered in the organization (Kuratko et al., 2014). Hornsby et al. (2002) support the claim that the appropriate reward system must encourage the entrepreneurial activity, focusing on goals, individual responsibility, results and feedback.

Monetary incentives, recognition through distinguishing marks or ceremonies, job design, increased responsibility, evaluation and sharing of people's innovative ideas constitute the examples of rewards and reinforcement of human resource practices which act independently or in combination (Hornsby et al., 1993; Perry-Smith, 2006). Flexible job design, which is characterized by job enrichment and teamwork, impels employees to act in a more proactive problem solving manner, pursuing more open-minded improvements (Ma Prieto \& Perez-Santana, 2014).

More entrepreneurial firms reward individual performance, with an emphasis on long-term effects, emboldening entrepreneurial behavior. Moreover, empirical research detects a positive correlation between the appropriate use of rewards and corporate entrepreneurship (Wood et al., 2008). However, it is well known that entrepreneurial and innovative behaviour is often connected with risk-taking (Hornsby et al., 2002), while it was not being undertaken in cases of nonreward systems (Meynhardt \& Diefenbach, 2012).

\section{Organizational boundaries}

Flexible organizational boundaries expedite information flow and sharing, boosting entrepreneurial behavior and ensuring productive and effective use of innovative available resources. Nevertheless, relatively structured processes are preferred over the chaotic ones, as uncertainty is maintained at manageable levels (Kuratko et al., 2014). Organizational boundaries contain the subcategories of formalization, centralization, technology routines and connectedness, as given below.

\section{Formalization}

It mainly refers to the extent to which formal rules, standard policies and procedures define decisions and working relationships (Holsapple \& Joshi, 2001). More flexibility and less formal work rules can increase creativity, openness, communication, variation, knowledge mining and creation (Jarvenpaa \& Staples, 2000).

There are indications that higher levels of alienation among public and private sector employees (Zeffane, 1994), welfare agency workers (Aiken \& Hage, 1966) and engineers (Greene, 1978) have been connected to formalization. Furthermore, there is a view point that accepts that formalization reduces stress through decrease of conflict and ambiguity role, providing guidance and clarifying job responsibility (Adler \& Borys, 1996).

Last but not least, there is the standpoint that increasing the level of organizational bureaucracy with more formalization may corroborate organizational commitment and constrain employees to comply with the organizational bureaucratic requirements (DeHart-Davis \& Pandey, 2005).

\section{Centralization}

Empirical evidence demonstrates that in an effort of achieving organizational control, centralized decision making is implemented and this action results in employee alienation (Zeffane, 1994). Higher levels of alienation between the public and the private welfare agencies (Aiken \& Hage, 1966) and public sector telecommunication workers (Zeffane, 1993) are connected with centralization. Seeman (1959) supports the fact that the lack of workplace autonomy increases alienation.

\section{Technology routines}

This factor may alienate public managers, although it does not constitute a direct form of organizational control. Indeed, there seems to be a positive correlation between technology routines and alienation (DeHart-Davis \& Pandey, 2005). 


\section{Connectedness}

Connectedness is mainly related to the decision-making process which is connected with communication channels in the organization.

\section{Organizational CUlture}

Organizational culture includes traits, values and beliefs of employees at all levels, where many of them are subconscious, and can be expressed through attitudes, behavior, feelings, relationships, language, physical settings, symbolisms and artifacts (Dobni, 2008; Zeffane, 1993).

Shared values, beliefs and expected behavior, which are the basic components of organizational culture, can have a bearing on innovation either through the process of socialization (Seeman, 1959) or through basic values, assumptions and beliefs (Chatman \& Jehn, 1994). Culture is of vital importance for organizational innovation, as it affects creativity and innovation through policies, structures, procedures and processes.

Organizational culture is the cornerstone in the process of organizational learning. An organization is characterized as a learning one if (Tesluk et al., 1997):

- its members are empowered,

- its members participate in the decisionmaking process and

- there is discretion in the administrative roles.

The existing literature concludes that there is a strong bond between innovativeness and culture (Dobni, 2008). Argyris and Schön (1996) reckon that the level of organizational innovativeness is linked with the culture that focuses on learning evolution and participative decision-making.

\section{Organizational learning}

Hurley and Hult (1998) consider organizational learning initially as knowledge acquisition which leads to value acquisition. It takes place when individuals act as learning agents for the organization and they are adapted to the internal and external environmental changes. Organizational learning, which constitutes a continuous and dynamic process, is the key to the firm's success (Sinkula et al., 1997).

Commitment to learning is defined as the extent to which an organization considers learning an important value (Sackmann, 1991). Commitment to learning is of vital importance for the intensity of organizational learning (Wang, 2008). Indeed, every experience is a learning opportunity. However, it is well-known that learning is a more effective continuous process when shared.

In general, learning orientation can be considered a system that generates and shares information. Learning orientation is a crucial perspective of organizational strategies and can optimize the outcome of the EO on the firm's performance (Covin et al., 2006).

A learning organization focuses on the attainment of erudition that could bring benefits to the organization, while Wang (2008) infers that the maximization of enterprise's performance can be achieved through cultivation of organizational learning. Within this frame, public policy should be learning-oriented. Public organizations are familiar with the learning process, they easily adjust to changes, improve their performances and evolve through knowledge management.

Certainly, the organization's learning ability is acquired by their members (Simon, 1969), and thus considerable attention should be devoted to this aspect. Learning ability of public organizations can be increased by adoption and implementation of feedback mechanisms and knowledge management systems. Thus, the appropriate conditions should be shaped in the internal and external working environment of each organization in order to foster organizational learning.

\section{Organizational commitment}

Porter (1974) defines it as deep beliefs which accept the goals and values of an organization. It highlights the quality of bonds between employees 
and organizations, and it stimulates public service motivation (Oliver, 1990). Organizational commitment is vital for quality assurance in the public sector (Romzek, 1990).

\section{Shared vision}

Shared vision implies the extent to which organizational goals are widely understood (Day, 1994). The vision affects the direction of learning (Wang, 2008). Shared vision guides individuals who are open-minded, committed to learning and motivated to learn in the right direction (Hurley \& Hult, 1998). Senge (1990) considers organizations as learning entities that share the organizational vision and approach to problem solving with openmindedness.

\section{Open-mindedness}

It refers to the degree to which an organization proactively disputes well established procedures, methods, assumptions, beliefs and convictions (Hurley \& Hult, 1998) which are related to the concept of "unlearning" (Nystrom \& Starbuck, 1984). The cultural openness to innovation is a cornerstone for innovativeness and can detect needs or opportunities for innovation.

\section{Job satisfaction}

This variable refers to the overall employee satisfaction with their job, supervisors, co-workers, payments, promotion opportunities, traders, occupational safety and conflict management. Job satisfaction forecasts entrepreneurial intentions (Eisenhauer, 1995; Watson et al., 1998). Furthermore, the theories on job satisfaction hypothesize that organizational climate determines job satisfaction (Agho et al., 1993) and employees are driven into entrepreneurship by low job satisfaction (Watson et al., 1998).

\section{Entrepreneurial Orientation (EO)}

According to Lumpkin and Dess (1996), it refers to an organization's or department's degree of entrepreneurship, namely processes, practices and decision-making activities which lead to a new entry. It can be measured through innovativeness, risk-taking and proactiveness (Currie et al., 2008; Miller, 1983).

Sharma and Chrisman (1999) define corporate entrepreneurship as the process which takes place at an organization where an individual or a group of individuals create a new organization or incite renewal or innovation within this specific organization. According to Kuratko et al. (2005), entrepreneurial behavior is the attitude and practice of corporate entrepreneurship which takes place at an individual level. Added value is created through EO.

In the public sector, EO is often measured by the "entrescale" (Miller, 1983; Covin \& Slevin, 1989). The findings of several empirical studies show that the firms with more EO perform better (Kuratko et al., 2005). Moreover, an afterwards meta-analysis of 37 studies reveals that firms benefit from (Sharma \& Chrisman, 1999). The more entrepreneurial the organization is, the more learning-oriented it becomes and it has more chances to endorse values that boost commitment to learning, open-mindedness and shared vision (Wang, 2008).

\section{Innovativeness}

It is defined as an organization's "tendency to engage in and support new ideas, novelty, experimentation and creative processes that may result in new products, services, or technological processes" (Lumpkin \& Dess, 1996, p. 142). Innovative behavior characterizes innovative organizations.

Dobni (2008) supports the claim that organizational innovativeness is a broad notion which can take a form from the intention to be innovative to the ability to introduce a new product, service or idea via the input of procedures, processes and systems, increasing potentially the organizational performance. Innovativeness is a dynamic organizational trait that appears overtime. 


\section{Proactiveness}

It refers to the extent to which an organization prevents, foresees, anticipates and acts towards future needs (Lumpkin \& Dess, 1996) and detecting new opportunities.

\section{Risk-taking}

It mainly refers to the extent to which "managers are willing to make large and risky resource commitments, i.e. those which have a reasonable chance of costly failures" (Covin \& Slevin, 1989, p. 923). Entrepreneurship carries certain amount of risk and uncertainty. The importance of risk-taking EO dimension is obvious given the fact that the level of external and internal organizational uncertainty is growing on a day-to-day basis. However, in the public sector, it follows a political process which is subject to the public law and requires legitimacy (Meynhardt \& Diefenbach, 2012).

\section{Resource availability}

Resource availability is prescribed as the accessibility and "availability of resources for innovative activities" (Hornsby et al., 2002, p. 253), such as financial resources (budget flexibility), human resources and time availability. The availability of these resources boosts experimentation, risk-taking attitudes and behavior. Indeed, there are several studies that focus on time availability among managers, as a component of vital importance for taking entrepreneurial initiatives (Kuratko et al., 2014).

\section{Ability to overcome barriers}

There are enough barriers to organizational innovation which may impede or lag an organization's efforts to evolve or induct novel or remarkably improved services, communication or organizational methods, procedures or processes. The examples of the above-stated could include:

- the absence of flexibility in statutes and bylaws (political factor),
- the lack of motivation and incentives for an organization as a whole to be innovative and/or

- the absence of budgetary funding (human or financial support).

Obstacles, such as the lack of collaboration, lack of management support, employee resistance to change, risk of failure and/or risk-averse culture, could be part of the organization and its culture. Barriers may be related to other internal conditions, such as scant time availability or lack of incentives for human resources to innovate. Finally, hurdles can constitute external junctures, such as user resistance to change or regulatory requisitions (Bloch \& Bugge, 2013).

\section{CONCLUSIONS}

Public administration places particular emphasis on the utilization of citizens' social welfare through services rendering within transparency framework, effectiveness of control and implementation of public policies. In order to be successful, structural changes must be accompanied by specific attitudes, behavior and efforts.

Slater and Narver (1995) have noticed that entrepreneurial organizations are innovative and risk-tolerant. Such behavior results in exploration and experimentation, thriving the organizational learning. In order to take advantage of entrepreneurial activities, an organization must be governed by the principles that are in compliance with learning commitment, open-mindedness towards change and shared vision.

The present article outlines the theoretical framework, describing how this leads organizational factors to EO through organizational culture and job satisfaction (moderators), under the influence of resources availability and the ability to overcome different barriers. In the society and the economy, as in biology, the phenomena of renewal and change are conditioned sine qua non of life and evolution. As in the private sector, the $\mathrm{EO}$ in public sector can be a useful means for achieving that. 
Through behavioral changes of obsolete bureaucratic procedures, the public sector can boost flexibility and EO, conserving simultaneously practices, processes and procedures that are essential for ensuring the quality of citizens' services.

Contemporary dynamic and changeable conditions advocate work environment that would encourage new ideas, innovation, pro-active behavior, risk-taking and rational management, reward experimentation and nurture maturity, readiness to change and open-mindedness. All this is crucial for an organization not only for adaptation and development, but also for viability reasons (Karyotakis \& Moustakis, 2015).

\section{Acknowledgment}

K. M. Karyotakis feels obliged to express his appreciation to the "George and Victoria Karelias Foundation" for the Karelia Foundation Scholarship grant.

\section{REFERENCES}

Adler, P.S., \& Borys, B. (1996). Two types of bureaucracy: Enabling and coercive. Administrative science quarterly, 41(1), 61-89. doi:10.2307/2393986.

Agho, A.O., Mueller, C.W., \& Price, J.L. (1993). Determinants of employee job satisfaction: An empirical test of a causal model. Human relations, 46(8), 10071027. doi:10.1177/001872679304600806.

Aiken, M., \& Hage, J. (1966). Organizational alienation: A comparative analysis. American Sociological Review, 31(4), 497-507.

Argyris, C., \& Schön, D.A. (1996). Organisational learning II: Theory, method and practice. Reading, MA: Addison-Wesley.

Bekkers, V.J.J.M., Hartley, J., \& Dawes, S.S. (2009). Innovation and the Public Sector. In Meijer, A., Boersma, K., and Wagenaar, P. (Eds.), ICTs, Citizens and Governance: After the Hype! Amsterdam, The Netherlands: IOS Press.

Benz, M. (2009). Entrepreneurship as a non-profitseeking activity. International Entrepreneurship and Management Journal, 5(1), 23-44. doi:10.1007/ s11365-006-0031-y.
Bloch, C., \& Bugge, M.M. (2013). Public sector innovation - From theory to measurement. Structural Change and Economic Dynamics, 27, 133-145. doi:10.1016/j.strueco.2013.06.008.

Bowen, D.E. (1986). Managing customers as human resources in service organizations. Human Resource Management, 25(3), 371. doi:10.1002/ hrm.3930250304.

Calantone, R.J., Cavusgil, S.T., \& Zhao, Y. (2002). Learning orientation, firm innovation capability, and firm performance. Industrial marketing management, 31(6), 515-524. doi:10.1016/S0019-8501(01)00203-6.

Chatman, J.A., \& Jehn, K.A. (1994). Assessing the relationship between industry characteristics and organizational culture: how different can you be? Academy of management journal, 37(3), 522-553. doi:10.2307/256699.

Collins, J.C. (2001). Good to great: Why some companies make the leap - and others don't. New York: Harper Business.

Covin, J.G., \& Slevin, D.P. (1989). Strategic management of small firms in hostile and benign environments. Strategic management journal, 10(1), 75-87. doi:10.1002/smj.4250100107.

Covin, J.G., Green, K.M., \& Slevin, D.P. (2006). Strategic process effects on the entrepreneurial orientationsales growth rate relationship. Entrepreneurship Theory and Practice, 30(1), 57-81. doi:10.1111/j.15406520.2006.00110.x.

Currie, G., Humphreys, M., Ucbasaran, D., \& McManus, S. (2008). Entrepreneurial leadership in the English public sector: paradox or possibility? Public Administration, 86(4), 987-1008. doi:10.1111/j.14679299.2008.00736.x.

Day, G.S. (1994). The capabilities of market-driven organizations. Journal of Marketing, 58(4), 37-52. doi: $10.2307 / 1251915$.

DeHart-Davis, L., \& Pandey, S.K. (2005). Red tape and public employees: Does perceived rule dysfunction alienate managers? Journal of Public Administration Research and Theory, 15(1), 133-148. doi:10.1093/ jopart/mui007.

Dobni, C.B. (2008). Measuring innovation culture in organizations: The development of a generalized innovation culture construct using exploratory factor analysis. European Journal of Innovation Management, 11(4), 539-559. doi:10.1108/14601060810911156.

Drucker, P. (1985). Entrepreneurship and innovation: Practice and principles. NY: Harper Business. 
Eisenhauer, J.G. (1995). The entrepreneurial decision: Economic theory and empirical evidence. Entrepreneurship: Theory and Practice, 19(4), 67-80.

Greene, C.N. (1978). Identification modes of professionals: Relationship with formalization, role strain, and alienation. Academy of Management Journal, 21(3), 486-492. doi:10.2307/255729.

Hamilton, R.T., \& Harper, D.A. (1994). The entrepreneur in theory and practice. Journal of Economic Studies, 21(6), 3-18. doi:10.1108/01443589410071391.

Holsapple, C.W., \& Joshi, K.D. (2001). Organizational knowledge resources. Decision support systems, 31(1), 39-54. doi:10.1016/S0167-9236(00)00118-4.

Hornsby, J.S., Kuratko, D.F., \& Zahra, S.A. (2002). Middle managers' perception of the internal environment for corporate entrepreneurship: assessing a measurement scale. Journal of Business Venturing, 17(3), 253-273. doi:10.1016/S08839026(00)00059-8.

Hornsby, J.S., Naffziger, D.W., Kuratko, D.F., \& Montagno, R.V. (1993). An interactive model of the corporate entrepreneurship process. Entrepreneurship: Theory and practice, 17(2), 29-38.

Hsu, I.C., Yeh-Yun Lin, C., Lawler, J.J., \& Wu, S.H. (2007). Toward a model of organizational human capital development: Preliminary evidence from Taiwan. Asia Pacific Business Review, 13(2), 251275. doi:10.1080/13602380701233547.

Hurley, R.F., \& Hult, G.T.M. (1998). Innovation, market orientation, and organizational learning: an integration and empirical examination. The Journal of Marketing, 62(3), 42-54. doi:10.2307/1251742.

Jarvenpaa, S.L., \& Staples, D.S. (2000). The use of collaborative electronic media for information sharing: an exploratory study of determinants. The Journal of Strategic Information Systems, 9(2), 129-154. doi:10.1016/S0963-8687(00)00042-1.

Kao, J.J. (1989). Entrepreneurship, creativity and organization. Eaglewood Cliffs, New Jersey: Prentice Hall.

Karyotakis, K.M., \& Moustakis, V.S. (2014). Reinvention of the public sector: Total quality management and change management. Singidunum Journal of Applied Sciences, 11(2), 30-44. doi:10.5937/ejae11-6751.

Karyotakis, K.M., \& Moustakis, V.S. (2015). Innovating in Public Administration. Paper presented at the $12^{\text {th }}$ Student Conference of Science and Technology, Athens University of Economics and Business \& Hellenic Management Association, Athens, 14 May (pp. 114-124). In Greek.
Karyotakis, K.M., Bakatsaki, M., \& Moustakis, V.S. (2015). The Entrepreneurial Facets Of Public Administration. Paper presented at the Synthesis International Scientific Conference of IT and BusinessRelated Research, Singidunum University, Belgrade, 16-17 April (pp. 327-331). doi:10.15308/Synthesis-2015-327-331.

Kearney, E., \& Gebert, D. (2009). Managing diversity and enhancing team outcomes: the promise of transformational leadership. Journal of Applied Psychology, 94(1), 77. doi:10.1037/a0013077.

Koch, P., \& Hauknes, J. (2005). On innovation in the public sector. Oslo: NIFU STEP.

Kuratko, D.F., Hornsby, J.S., \& Covin, J.G. (2014). Diagnosing a firm's internal environment for corporate entrepreneurship. Business Horizons, 57(1), 37-47. doi:10.1016/j.bushor.2013.08.009.

Kuratko, D.F., Ireland, R.D., Covin, J.G., \& Hornsby, J.S. (2005). A Model of Middle-Level Managers' Entrepreneurial Behavior. Entrepreneurship theory and practice, 29(6), 699-716. doi:10.1111/j.15406520.2005.00104.x.

Leadbeater, C., \& Goss, S. (1998). Civic entrepreneurship. London: Demos Publication.

Lumpkin, G.T., \& Dess, G.G. (1996). Clarifying the entrepreneurial orientation construct and linking it to performance. Academy of management Review, 21(1), 135-172.

Ma Prieto, I., \& Pilar Perez-Santana, M. (2014). Managing innovative work behavior: the role of human resource practices. Personnel Review, 43(2), 184-208. doi:10.1108/PR-11-2012-0199.

Martins, E.C., \& Terblanche, F. (2003). Building organisational culture that stimulates creativity and innovation. European journal of innovation management, 6(1), 64-74. doi:10.1108/14601060310456337.

Meynhardt, T., \& Diefenbach, F.E. (2012). What Drives Entrepreneurial Orientation in the Public Sector? Evidence from Germany's Federal Labor Agency. Journal of Public Administration Research and Theory, 22(4), 761-792. doi:10.1093/jopart/mus013.

Miller, D. (1983). The correlates of entrepreneurship in three types of firms. Management science, 29(7), 770-791.

Moustakis, V. (2012). Administrative technology. Greece, Chania: Disigma. In Greek.

Nystrom, P.C., \& Starbuck, W.H. (1984). To avoid organizational crises, unlearn. Organizational dynamics, 12(4), 53-65. 
Oliver, N. (1990). Rewards, investments, alternatives and organizational commitment: Empirical evidence and theoretical development. Journal of Occupational Psychology, 63(1), 19-31. doi:10.1111/j.2044-8325.1990.tb00507.x.

Parker, S.K., Williams, H.M., \& Turner, N. (2006). Modeling the antecedents of proactive behavior at work. Journal of Applied Psychology, 91(3), 636. doi:10.1037/0021-9010.91.3.636.

Perry-Smith, J.E. (2006). Social yet creative: The role of social relationships in facilitating individual creativity. Academy of Management Journal, 49(1), 85-101. doi:10.5465/AMJ.2006.20785503.

Porter, L.W., Steers, R.M., Mowday, R.T., \& Boulian, P.V. (1974). Organizational commitment, job satisfaction, and turnover among psychiatric technicians. Journal of Applied Psychology, 59(5), 603. doi:10.1037/h0037335.

Romzek, B.S. (1990). Employee investment and commitment: The ties that bind. Public Administration Review, 50(3), 374-382.

Sackmann, S.A. (1991). Cultural knowledge in organizations: Exploring the collective mind. Newbury Park, CA: Sage.

Schumpeter, J.A. (1934). The Theory of Economic Development. Boston, MA: Harvard University Press.

Scott, R.D. (2001). Organizations and Institutions. Stanford, CA: Stanford University Press.

Seeman, M. (1959). On the meaning of alienation. American sociological review, 783-791.

Senge, P.M. (1990). The fifth discipline: The art and practice of the learning organization. US: Currency Doubleday.

Sharma, P., \& Chrisman, S.J.J. (1999). Toward a reconciliation of the definitional issues in the field of corporate entrepreneurship. Entrepreneurship Theory and Practice, 23(3), 11-27. doi:10.1007/978-3-54048543-8_4.

Shockley, G.E., Frank, P.M., \& Stough, R.R. (2002). Toward a theory of public sector entrepreneurship. Paper presented at the NCIIA $7^{\text {th }}$ Annual Meeting: Big Ideas in a Small World, Boston, MA, 20-22 March.

Simon, H.A. (1969). The architecture of complexity. In The Sciences of the Artificial (pp. 192-229). Cambridge, MA: MIT Press.

Sinkula, J.M., Baker, W.E., \& Noordewier, T. (1997). A framework for market-based organizational learning: Linking values, knowledge, and behavior. Journal of the academy of Marketing Science, 25(4), 305-318.
Slater, S.F. \& Narver, J.C. (1995). Market orientation and the learning organization. Journal of Marketing, 59(3), 63-74. doi:10.2307/1252120.

Tesluk, P.E., Farr, J.L., \& Klein, S.R. (1997). Influences of organizational culture and climate on individual creativity. The Journal of Creative Behavior, 31(1), 27-41. doi:10.1002/j.2162-6057.1997.tb00779.x.

Wang, C.L. (2008). Entrepreneurial orientation, learning orientation, and firm performance. Entrepreneurship theory and practice, 32(4), 635-657. doi:10.1111/ j.1540-6520.2008.00246.x.

Watson, R.T., Zinyowera, M.C., \& Moss, R.H. (1998). The regional impacts of climate change: an assessment of vulnerability. UK: Cambridge University Press.

Wood, C.C., Holt, D.T., Reed, T.S., \& Hudgens, B.J. (2008). Perceptions of corporate entrepreneurship in air force organizations: antecedents and outcomes. Journal of Small Business and Entrepreneurship, 21(1), 117-131. doi:10.1080/08276331.2008.1 0593416.

$\mathrm{Wu}$, J. (2011). Asymmetric roles of business ties and political ties in product innovation. Journal of Business Research, 64(11), 1151-1156. doi:10.1016/j.jbusres.2011.06.014.

Yuan, F., \& Woodman, R.W. (2010). Innovative behavior in the workplace: The role of performance and image outcome expectations. Academy of Management Journal, 53(2), 323-342. doi:10.5465/ AMJ.2010.49388995.

Zampetakis, L.A. (2007). Methodology for the development of entrepreneurship in public sector (Doctoral dissertation). Technical University of Crete, Greece. In Greek.

Zampetakis, L.A., \& Moustakis, V. (2007). Entrepreneurial behaviour in the Greek public sector. International Journal of Entrepreneurial Behavior and Research, 13(1), 19-38. doi:10.1108/13552550710725165.

Zampetakis, L.A., \& Moustakis, V.S. (2010). An exploratory research on the factors stimulating corporate entrepreneurship in the Greek public sector. International Journal of Manpower, 31(8), 871-887. doi:10.1108/01437721011088557.

Zeffane, R. (1993). Uncertainty, participation and alienation: Lessons for workplace restructuring. International Journal of Sociology and Social Policy, 13(5/6), 22-52. doi:10.1108/eb013174.

Zeffane, R. (1994). Patterns of organizational commitment and perceived management style: A comparison of public and private sector employees. Human Relations, 47(8), 977-1010. doi:10.1177/001872679404700806. 


\section{ORGANIZACIONI FAKTORI, ORGANIZACIONA KULTURA, ZADOVOLJSTVO POSLOM I PREDUZETNIČKA ORIJENTACIJA U DRŽAVNOJ ADMINISTRACIJI}

\section{Rezime:}

U radu se ispituje značaj i uticaj organizacione kulture i zadovoljstva poslom na odnos između organizacionih faktora i preduzetničke orijentacije u državnom sektoru kreiranjem i razmatranjem teorijskog okvira. Nakon temeljne analize pomenutih pojmova, autori prikazuju model koji najbolje ukazuje na njihove međusobne odnose. Amalgam internog radnog okruženja, poslovna diskrecija i nagrade/priznanja, uz pojedina ograničenja unutar same organizacije, poput formalizacije, centralizacije, rutine u primeni tehnologije i povezanosti, od presudnog su značaja za negovanje organizacione kulture i zadovoljstva poslom koji razvijaju preduzetničku orijentaciju kroz inovativnost, proaktivnost i spremnost za preuzimanje rizika.

\section{Ključne reči:}

organizaciona kultura, organizacija koja uči, zadovoljstvo poslom, preduzetnička orijentacija, javni sektor. 